\title{
Does a female CEO and female directors affect dividend policy?
}

\author{
Fitri Ismiyanti, Ari Prasetyo \& Indri Agestya Cania \\ Airlangga University, Surabaya, Indonesia
}

\begin{abstract}
This study aims to determine the influence of female CEO and female directors on the dividend policy of nonfinancial companies listed on Indonesia Stock Exchange. This study used purposive sampling method with 372 samples. Dividend policy was measured by dividend payout ratio defined as dividend over net income. The result of multiple linear regression showed that female board has a significant positive effect on dividend policy, or in other words, female board increases the dividend policy. Otherwise, female CEO has no significant effect on dividend policy.
\end{abstract}

Keywords: female director, female CEO, dividend

\section{RESEARCH BACKGROUND}

Managers have an obligation to make the company grows beyond its optimal size. Company growth can increase manager flexibility by increasing free cash flow under their control. A corporate cash increase is also associated with a manager's compensation increase because compensation changes have a positive effect on sales growth (Murphy 1985). Great manager control over the company's cash flow raises shareholder concerns that they will not get any return on their investments. Thereby, shareholders demand a dividend rather than reinvest the excess cash. Jensen (1986) argues that conflicts between shareholders and managers can be reduced by dividend distribution to shareholders.

Easterbrook (1984) states that there are two factors that can influence the agency costs of a company, namely the cost of supervision and risk aversion preference of managers. According to him, dividend payouts can be used to minimize agency costs when supervision costs are low. High supervisory costs to managers can lower shareholder wealth. Thereby, shareholders need good supervisors in order to improve their welfare through dividend payouts. A risk-averse manager is driven by concerns about losing their jobs and wealth if the company goes bankrupt. Thereby, managers tend to choose to be a risk aversion. The risk-averse manager takes investment decisions very carefully to avoid bankruptcy. This research argue that more gender diverse councils can lead to better market understanding, an increase in creativity and innovation, and a positive effect on consumer behavior by enhancing the company's image that drives maximum profitability. Chen (2016) in his research related to the composition of directors revealed a positive influence of the existence of female directors to dividend payout. Adams and Ferreira (2009) state that if female also actively participate in board meetings and oversight committees; they can increase the intensity of supervision.

Conflicts of interest lead to the concept of agency theory that forms the theoretical model of corporate governance used in companies worldwide (Walt \& Ingley, 2003). Corporate governance provides an alternative solution to resolve agency conflicts between management and shareholders. Corporate governance mechanisms are expected to serve as a tool to give investors' confidence that they will receive a return on the funds they have invested (Schleifer \& Vishny 1997). Forbes \& Milliken (1999) argue that effective female CEO must be cognitively independent and critical-minded. Like having a different point of view and the decisions proposed by the executive can be well researched. Based on the above description of the background, then the formulation of this research problem is as follows:

1. Does female CEO affect the company's dividend policy?

2. Whether female directors influence the company's dividend policy? 


\section{LITERATURE REVIEW}

\subsection{The Influence of Existence of Female CEO on Dividend Policy}

Adams \& Ferreira (2009) state that female attend meetings more often and are more likely to be assigned to committees that relate to supervision than male. If female also actively participates in board meetings and oversight committees, they can increase the intensity of oversight of the board of directors. Female is able to align their interests with the interests of shareholders. Harvey \& Allard (2009) expressed different opinions about the existence of female CEO that there is a characteristic difference between male and female in terms of leadership style and risk. A male is always identical with masculinity, firmness, and competition while a female is identical with cooperation and coaching. This can lead to intra-group conflicts that slow down the decision-making process. Such conflicts can add to agency costs that can dampen corporate earnings. The decrease in corporate profits can reduce the dividends to be paid to shareholders.

$\mathrm{H}_{1}$ : The existence of female $\mathrm{CEO}$ has a positive effect on the dividend policy.

\subsection{The Influence of Existence of Female Directors on Dividend Policy}

The existence of female directors remains a minority in some companies. Chen (2016) sees this as a good thing because female directors can be more competitive and make decisions that avoid groupthink. This makes female directors more independent and is expected to make decisions that can benefit shareholders. This can improve managerial direction, thus bringing benefits to stakeholders. According to Carter (2003), the female has a high degree of caution, tends to avoid risk, and more thorough in the decision- making. This research argue that a more diverse board in terms of gender can lead to better market understanding and an increase in creativity and innovation that have a positive effect on consumer behavior by enhancing the company's image. It can increase the company's earnings and positive response from the stock market. Corporate profit increase is a good signal for shareholders as they relate to dividend payments to be received.

$\mathrm{H}_{2}$ : The existence of female directors has a positive effect on the dividend policy.

\section{RESEARCH METHODS}

\subsection{Operational Definition and Variable Measurement}

The dependent variable in this research is a dividend, while the independent variables used in this research are female CEO and directors. The dividend measurement was done by dividing the dividend with net income, while the measurement of the female CEO is the proportion of female CEO compared to the total number of board of commissioners in a company. The female directors were measured by dividing the proportion of female directors with the total number of directors. This research also used control variable that is among others return on asset, leverage, size of directors, and board size of a commissioner.

\subsection{Research Model}

The analytical technique used in this study was mul-

$$
D P R_{i, t}=\beta_{0}+\beta_{1} F C E O_{i, t}+\beta_{2} F D+\beta_{3} R O A_{i . t}
$$

tiple linear regression analysis to determine the effect of the existence of female CEO and female directors on the company's dividend policy. The model of analysis in this study was:

Information:

$\begin{array}{lll}\text { DPR }_{\text {it }} & : & \text { dividend payout ratio } \\ \text { FCEO }_{\text {it }} & : \text { female CEO } \\ \text { FD }_{\text {it }} & : & \text { female directors } \\ \text { ROA }_{\text {it }} & : & \text { return on asset } \\ \text { LEV }_{\text {it }} & : & \text { leverage } \\ \text { BOCSIZE }_{\text {it }} & : & \text { number of commissioners } \\ \text { BODSIZE }_{\text {it }} & : \text { number of directors }\end{array}$

\section{RESULT AND DISCUSSION}

The results of regression analysis indicate that the existence of female commissioners does not affect the dividend policy as measured by dividend payout ratio. Dividend payout ratio is the dividend measurement paid by the company. This result is inconsistent with Harvey \& Allard (2009) research which found that differences in the characteristics of male and female commissioners can lead to intra-group conflict. Such conflicts can add to agency costs that can dampen corporate earnings. A decrease in corporate profits can reduce the dividends to be paid to shareholders. This is in line with the role of the board of commissioners as the supervisor of the company without participating in the decisionmaking operations of the company (KNKG 2006). It can also be interpreted that supervision by the board 
of commissioners of non-financial companies in Indonesia does not depend on dividend policy in overcoming agency problems.

Table 4.1 Results of Regression Analysis

\begin{tabular}{llll}
\hline \multirow{2}{*}{ Independent Variable } & \multicolumn{3}{l}{ Regression Model } \\
\cline { 2 - 4 } & Coefficient & T-stat & Sig. \\
\hline Constant & 0.208 & 5.780 & 0.000 \\
Female Directors & -0.030 & -0.524 & 0.600 \\
Female CEO & 0.135 & 2.166 & $0.031^{*}$ \\
Return On Asset & 0.593 & 5.726 & $0.000^{*}$ \\
Leverage & -0.110 & -0.231 & $0.021^{*}$ \\
Number of Directors & 0.010 & 1.925 & 0.055 \\
Number of Commisioners & -0.006 & -0.983 & 0.326 \\
$\mathrm{R}^{2}$ & 0.141 & & \\
\hline
\end{tabular}

The results of regression testing of this study indicate that the existence of female directors has a positive effect on dividend policy as measured by dividend payout ratio. Dividend payout ratio is the dividend measurement paid by the company. This result is in accordance with the proposed hypothesis. It can be interpreted that companies with female directors have higher dividend payout rates. Thus, the female directors are considered able to realize the expectations of shareholders. The presence of diversity within the board is viewed as a benefit to the company. Such diversity can encourage a better understanding of the market because a group of people with different backgrounds and experiences have a tendency to solve similar problems in different ways (Ferreira 2010). Gender diversity can boost leadership effectiveness within a company. Female is considered more prudent, tends to avoid risk, and more accurate in making decisions than male. The results of this study are consistent with research conducted by Chen (2016) which states that the existence of female directors in the company has a positive effect on dividend payout. The board of directors has the authority to make operational decisions such as dividend payout. This may signify that shareholders with more female directors in the company can increase dividend income by shareholders.

\section{CONCLUSIONS}

This study aims to examine the effect of female directors and CEO on dividend policy by using control variable return on asset, leverage, board size, and board size. Based on the analysis, it is concluded that female directors, ROA, and leverage have an influence on dividend policy, while female commissioner board, board size, and board size have no effect on dividend policy. Gender diversity can boost leadership effectiveness within a company. Female is considered more prudent, tends to avoid risk, and more accurate in the decision-making than male.

\section{REFERENCES}

Adams, R. \& D. Ferreira. 2009. Woman in the boardroom and their impact of governance and performance. Journal $\mathrm{Fi}$ nance Economics 94: 291-309.

David C., S.J. Betty \& W. Simpson. 2003. Corporate Governance, Board Diversity and Firm Value. The Financial Review 38(1): 33-53.

Carter, D.A. 2003. Corporate Governance, Board Diversity, and Firm Value. The Financial Review 38(2003): 33-53.

Chen, J., W.S. Leung, \& Marc, G. 2016. The Impact of Board Gender Composition on Dividend Payouts. Journal of Corporate Finance 43(1): 86-105.

Easterbook, F. H. 1984. Two Agency Cost Explanations of Dividens. American Economic Studies 74:650-659.

Ferreira, D. 2010. Corporate Governance: A Synthesis of Theory, Research, and Practice Chapter 12 Board Diversity. Wiley Publisher.

Forbes, D.P. \& Milliken, F.J. 1999. Cognition and Corporate Governance: Understanding Boards of Directors as Strategic Decision Making Groups. Academy of Management Review, 24(3): 489-505.

Harvey, C. P. \& Allard, M. J. 2012. Understanding and Managing Diversity. New Jersey: Pearson Education, Inc: xii-393.

Jensen, M.C. 1986. Agency Cost of Free Cashflow, Corporate Finance, and Takeovers. The American Economic Review 76(2): 323-329.

Murphy, K. J. 1985. Corporate performance and managerial remuneration: An empirical analysis. Journal of Accounting and Economics 7(1-3): 11-42.

KNKG. 2006. Pedoman Umum Good Corporate Governance Indonesia.

Shleifer, A. \& R. Vishny. 1997. A Survey of Corporate Governance. Journal of Finance 52:737-783.

Walt, N. V. D. \& Ingley. 2003. Board Dynamics and The Influence of Professional Background, Gender, and Ethic Diversity of Directors Corporate Governance. International Review 11(3): 218-234 